TAPROBANICA, ISSN 1800-427X. October, 2012. Vol. 04, No. 02: pp. 69-76.

(C) Taprobanica Private Limited, 146, Kendalanda, Homagama, Sri Lanka.

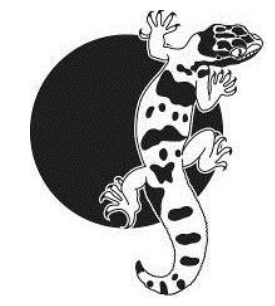

\title{
BOLBOCERATINE SCARABS OF GENERA Bolbohamatum KRIKKEN, 1980 AND Bolbogonium BOUCOMONT, 1911 (COLEOPTERA: GEOTRUPIDAE) FROM CENTRAL INDIA
}

\section{Kailash Chandra ${ }^{1}$ and Devanshu Gupta ${ }^{2}$}

\footnotetext{
${ }^{1}$ Zoological Survey of India, New Alipore, Kolkata 700053, West Bengal, India E-mail: kailash611@ rediffmail.com

${ }^{2}$ Zoological Survey of India, Jabalpur 482002, Madhya Pradesh, India

E-mail: devanshuguptagb4102@gmail.com
}

\begin{abstract}
This study includes a taxonomic account of four species of genus Bolbohamatum; B. calanus (Westwood, 1848), B. phallosum Krikken, 1980, B. marginale Krikken, 1980 and B. laterale (Westwood, 1848) and one species of genus Bolbogonium; B. insidiosum Krikken, 1977 from Central India (Madhya Pradesh and Chhattisgarh). The pronotal ornamentation and external male genitalia of Bolbohamatum species has been diagnosed with the incorporation of an identification key to the species from Central India. A checklist containing 19 Indian species of both genera (Bolbohamatum and Bolbogonium) has also been prepared with their distribution in different states of India as well as outside of India.
\end{abstract}

Keywords: dung beetles, pronotal ornamentation, external male genitalia, distribution, India.

\section{Introduction}

Bolboceratine scarabs in the family Geotrupidae are commonly called Earth-boring dung beetles because adults of most species provision larvae in earthen burrows with dead leaves, cow dung, horse dung, or humus. The family Geotrupidae currently includes 620 species belonging to 68 genera in three subfamilies; Taurocerastinae, Bolboceratinae and Geotrupinae (Scholtz \& Browne, 1996). The first comprehensive study of Asian Bolboceratinae was carried out by Westwood
(1848, 1852), which considered 29 species to be in one genus Bolboceras. Later, several new species names were added based on the materials from tropical and eastern Asia. Boucomont (1911) proposed Bolbogonium as a subgenus for Bolboceras. A series of taxonomic publications on Asian Bolboceratinae were then made by Krikken (1977ab, 1978ab, 1979, 1980, 1984), Carpaneto et al. (1993), Masumoto (1984), Li et al. (2008), Nikolajev (1979ab, 2003, 2008), Ochi 
\& Kawahara (2002), Ochi \& Masumoto (2005) and Ochi et al. (2010, 2011). Krikken (1977a,b) raised the subgenus Bolbogonium to the genus level and described seven new species, along with producing a key to all ten Asian species. Subsequently, Krikken (1980) proposed the genus Bolbohamatum for four species to be combined with Bolboceras, while also describing nine new species and discussing the significance of external male genitalia and pronotal ornamentation in the accurate identification of the various species. Recently, Karl et al. (2006) catalogued Bolboceratine scarabs of the Palaearctic region. The present study includes taxonomic information for four species of Bolbohamatum and one species of Bolbogonium from the Madhya Pradesh and Chhattisgarh states in India and also incorporates new distributional records of these beetles. A checklist of both genera from India is included.

\section{Materials and methods}

Specimens for the study were collected using light trap from various protected areas by scientific teams of ZSI based in Jabalpur, Madhya Pradesh. Pinned specimens were identified with the help of available taxonomic revisions of the studied genera (Krikken, 1977b, 1980). Specimens were examined under a binocular microscope (Leica M205 A) and photographs were taken with the help of an attached digital camera. Male specimens were dissected, with the abdomen separated from the body and the aedeagus extracted from the abdomen. The genitalia were then cleaned and softened in a dish of hot water and further cleaned in a hot water solution of $10 \% \mathrm{KOH}$. All parts of the aedeagus were washed in $95 \%$ ethanol and photographed. After examination, the genitalia were stored in a glass vial containing $70 \%$ ethanol.

The details of specimens examined, registration number of specimens, distribution inside and outside India, main diagnostic characters, description, illustration of external male genitalia, and identification key to the species level within the genus Bolbohamatum are provided. The classification adopted in the article is after Smith (2006). Identified specimens were deposited in ZSI, Jabalpur, Madhya Pradesh (India).

\section{Results and Discussion}

Four species of the genus Bolbohamatum; $B$. calanus (Westwood 1848), B. phallosum Krikken 1980, B. marginale Krikken 1980 and B. laterale (Westwood 1848) and one species of genus Bolbogonium; B. insidiosum Krikken 1977 were studied from the states Madhya Pradesh and Chhattisgarh. Bolbohamatum calanus, B. laterale and B. phallosum are recorded for the first time from Madhya Pradesh, while Bolbohamatum marginale and $B$. calanus constitute new reports for Chhattisgarh. The identification of these species is based on the structure of external male genitalia, pronotal ornamentation and clypeal dentations, which are shown in figures 1 to 9. Bolbogonium insidiosum shows variations in the structure of clypeofrons (Fig. 9). The checklist for 19 Indian species of both Bolbohamatum (11 species) and Bolbogonium (8 species), along with their distribution within and outside of India, are provided in Table 1.

\section{Systematic Account}

\section{Family: Geotrupidae Latreille, 1802 \\ Subfamily: Bolboceratinae Mulsant, 1842 \\ Tribe: Eubolbitini Nikolajev, 1970}

\section{Genus Bolbohamatum Krikken, 1980}

Bolbohamatum Krikken, 1980: 5 (Type species: Scarabaeus cyclops Olivier, 1789: 60)

The genus includes the species, presenting one of the largest Bolboceratine scarabs which are distributed in both the Palaearctic and Oriental geographic regions. It likely evolved on the Indian subcontinent and spread at a relatively late stage through Myanmar into Sundaland and China (Krikken, 1980).

Generic diagnosis: Metasternum anterroiorly always with a small spiniform protrusion and with anterior lobe narrowly separating middle coxae. Head of males with a pair of tubercles on clypeus. Pronotum in case of male possess median and lateral protrusions with the surface between them usually concave. Fore tibia with 7-10 external denticles. 


\section{Identification key to the species of Bolbohamatum Krikken, 1980 from Central India:}

1. Lateral tubercles of pronotum well developed but not marginally situated. Apex of parameres not with reflexed paramerites

Lateral tubercles of pronotum well developed or completely reduced or absent if present then marginally situated. Apex of parameres dorsally with short reflexed paramerites

2. Dorsally the parameres moderately sclerotized, relatively narrow and with poorly developed paramerite. Ventral side of parameres devoid of distinct paramerites. Basal capsule relatively narrow

Bolbohamatum calanus

Dorsally the parameres foliate and ventrally with a pair of more or less glider-like paramerites. Basal capsule in lateral view distally strongly emarginated

Bolbohamatum phallosum

3. Paramedian tubercles of pronotum closely approximated and separated by less than to interocular distance while lateral tubercles well developed and marginally situated Bolbohamatum marginale

Paramedian tubercles of pronotum not closely approximated and separated by more than inter-ocular distance while lateral tubercles absent

Bolbohamatum laterale

Bolbohamatum calanus (Westwood, 1848)

Bolboceras calanus Westwood, 1848a: 385, (description, distribution).

Bolboceras tumidulus Westwood, 1852: 22, (description, distribution, illustration).

Bolbohamatum calanus Krikken, 1980: 20, (description, keyed, distribution, illustration, comb. nov.).

Specimens examined: Chhattisgarh: ZSI/CZRC-A/16601; male (Length: $15.0 \mathrm{~mm}$; width: $10.0 \mathrm{~mm})$; Barnavapara camp, Barnavapara Wildlife Sanctuary, Raipur $\left(21^{\circ}\right.$ $24.00^{\prime} \mathrm{N}, 82^{\circ} 25.314^{\prime} \mathrm{E}$; alt. $303.8 \mathrm{~m}$ ); K. Chandra \& party, 01 July 2011, light trap. Madhya Pradesh: ZSI/CZRC-A/16602; male (Length: $16.0 \mathrm{~mm}$; width: $9.0 \mathrm{~mm}$ ); Forest Rest House, Bandhavgarh National Park, Umaria, K. Chandra, 10 August 2005, light trap; ZSI/CZRC-A/16603; male (Length: $17.0 \mathrm{~mm}$; width: $9.0 \mathrm{~mm}$ ), Karmajhiri, Pench Tiger Reserve, Seoni; K. Chandra, 13 June 2001.

Diagnosis: (Fig. 1). Brown, shiny and pilosity yellow brown. Cephalic tubercles more or less dentiform, isolated and placed simply on clypeal disc. Dorsal outline of left mandible sinuate lobate. Pronotum with a pair of feebly developed, slightly transverse median tubercles with lateral callosities. Pronotum abundantly punctate, but never densely punctate throughout. Paramedian tubercles separated by less than inter-ocular distance. Lateral impression of pronotum shallow.

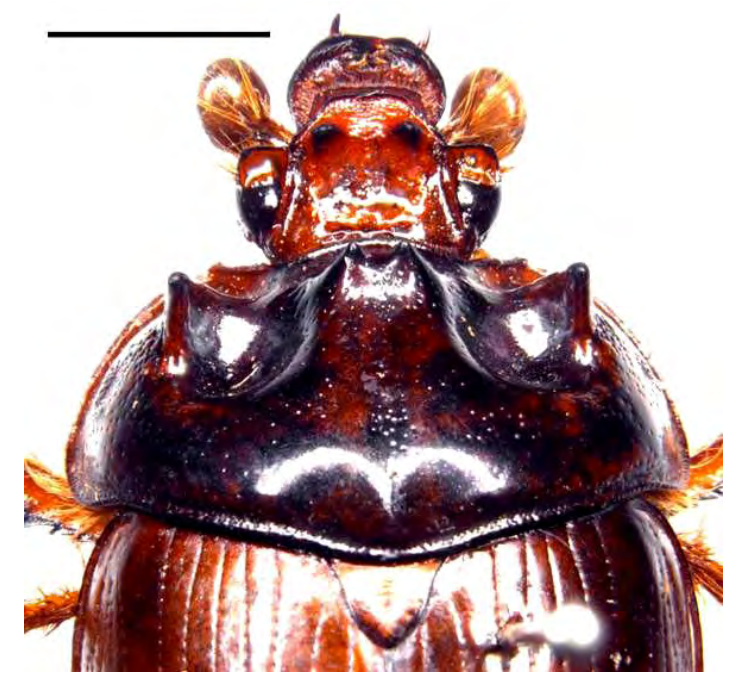

Figure 1: B. calanus (scale: $5 \mathrm{~mm}$ ), ZSI/CZRCA/16601, Barnawapara Wildlife Sanctuary, 2011.

External male genitalia: (Fig. 2) Dorsally, the parameres moderately sclerotized, relatively narrow and with poorly developed paramerite while the ventral side of parameres devoid of distinct paramerites. Basal capsule relatively narrow.

Geographical distribution: India: Assam, Bihar, Chhattisgarh, Karnataka, Madhya 
Pradesh, Maharashtra, Tamil Nadu, West Bengal and Uttarakhand. Elsewhere: Bangladesh and Java.

New state and district record: Chhattisgarh (Raipur) and Madhya Pradesh (Umaria and Seoni).

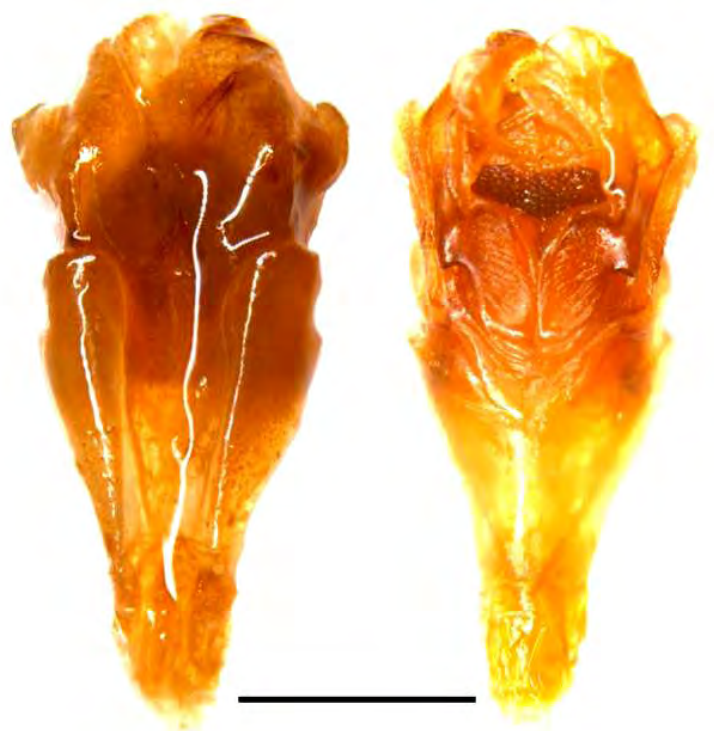

Figure 2: Dorsal \& ventral view of external male genitalia of B. calanus (scale: $2 \mathrm{~mm}$ ), ZSI/CZRCA/16601.

Bolbohamatum phallosum Krikken, 1980 Bolbohamatum phallosum Krikken, 1980: 21, (description, keyed, distribution, illustration).

Specimens examined: Madhya Pradesh: ZSI/CZRC-A/16604; male (Length: $15.0 \mathrm{~mm}$; width: $9.0 \mathrm{~mm}$ ); Turiya, Pench Tiger Reserve, Seoni; K. Chandra, 23 June 2001; light trap; ZSI/CZRC-A/16779; male (Length: $17.0 \mathrm{~mm}$; width: $11.0 \mathrm{~mm}$ ); Kisli Rest House, Kanha National Park, Mandla; M. Limje \& party, 13 September 2003; light trap; ZSI/CZRCA/16780; male (Length: 16.0 mm; width: 10.0 $\mathrm{mm}$ ); Kisli Rest House, Kanha National Park, Mandla; M. Limje \& party; 09 September 2003.

Diagnosis: (Fig, 3). Brown, shiny and pilosity yellow brown. Clypeus with a pair of dentiform tubercles. Pronotum with closely approximated paramedian tubercles and lateral protrusion not shifted to antero-lateral corner. Juxtasutural punctures of elytra sub obsolete and discal striae shallowly impressed and finely punctate. Elytral inter-striae very slightly convex and minutely and sparsely punctured.

External male genitalia: (Fig. 4) Dorsally, parameres foliate and ventrally with a pair of more or less glider-like paramerites. In lateral view, the basal capsule distally strongly emarginated.

Geographical distribution: India: Madhya Pradesh, Maharashtra and East India.

New state and district record: Madhya Pradesh (Seoni and Mandla).

Remarks: B. calanus (Westwood, 1848) and B. phallosum Krikken, 1980 show close resemblance in their morphological characters and cannot be separated on the basis of external characters only, but the phalli of both the species are very different and only the characters of the phallus distinguish both the species.

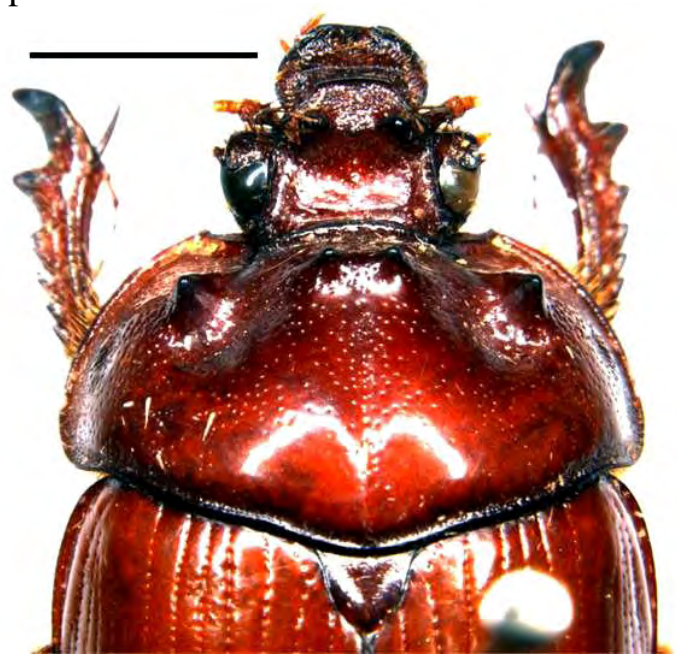

Figure 3: $B$. phallosum (scale: $5 \mathrm{~mm}$ ), ZSI/CZRCA/16604, Pench Tiger Reserve, 2001.

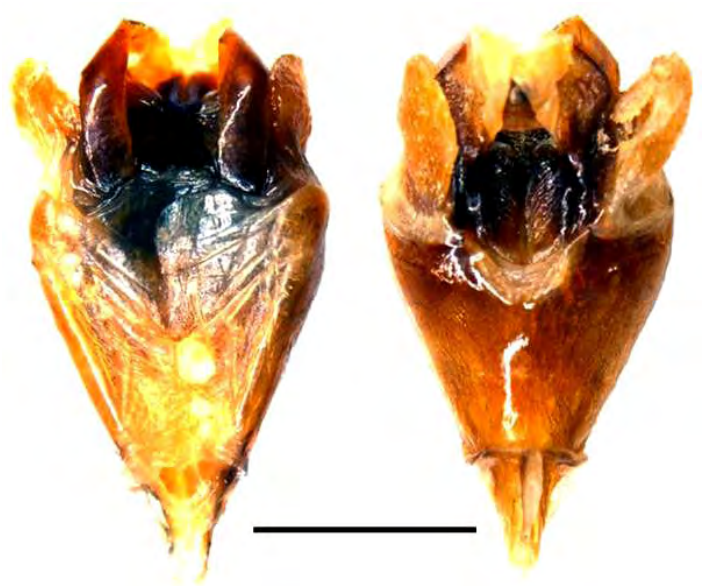

Figure 4: Dorsal \& ventral view of external male genitalia of B. phallosum (scale: $2 \mathrm{~mm}$ ), ZSI/CZRCA/16604.

Bolbohamatum marginale Krikken, 1980 Bolbohamatum marginale Krikken, 1980: 30, (description, keyed, distribution, illustration).

Specimens examined: Chhattisgarh: ZSI/CZRC-A/16599; male (Length: $16.0 \mathrm{~mm}$; 
width: $9.0 \mathrm{~mm}$ ); Ataria Forest House, Amarkantak Biosphere Reserve, Bilaspur; A. Singh \& party; 18 April 2004; light trap. Madhya Pradesh: ZSI/CZRC-A/16600; male (Length: $15.0 \mathrm{~mm}$; width: $9.0 \mathrm{~mm}$ ); Kisli, Kanha National Park, Mandla; M. Limje \& party, 13 September 2003; light trap.

Diagnosis: (Fig. 5). Dorsal outline of left mandible lobate. Clypeus with a pair of dentiform tubercles each placed against lateral margin. Pronotum with strongly approximated paramedian tubercles and a pair of lateral tubercles situated almost marginally. Median longitudinal zone and lateral declivities of pronotum densely and coarsely punctured while impression between paramedian and lateral tubercles virtually devoid of punctures and opaque. Fore tibia with seven external denticles.

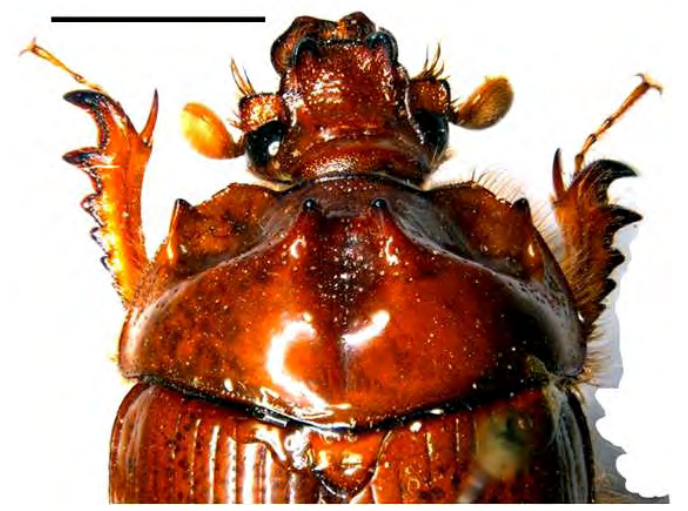

Figure 5: $B$. marginale (scale: $5 \mathrm{~mm}$ ), ZSI/CZRCA/16599, Amarkantak Biosphere Reserve, 2004.

External male genitalia: (Fig. 6) Parameres reduced and basal capsule enlarged. Basal capsule of the phallus very robust in comparison to B. laterale (Westwood, 1848) and B. kuijteni Krikken, 1980.

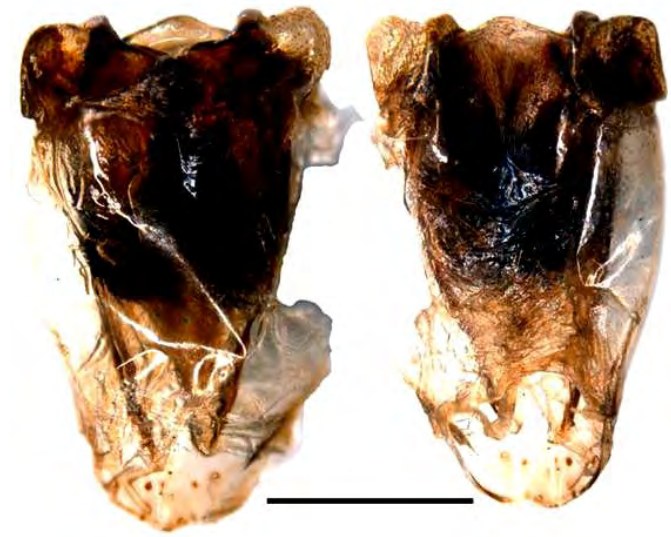

Figure 6: Dorsal \& ventral view of external male genitalia of $B$. marginale (scale: $2 \mathrm{~mm}$ ), ZSI/CZRCA/16599.
Remarks: The species can be easily distinguished from its close relatives in having pronotal lateral tubercles situated almost marginally and very closely approximated paramedian tubercle.

Geographical distribution: India: Chhattisgarh, Madhya Pradesh, Tamil Nadu, Karnataka and Uttarakhand. Elsewhere: West Pakistan.

New state and district record: Chhattisgarh (Bilaspur) and Madhya Pradesh (Mandla).

\section{Bolbohamatum laterale (Westwood, 1848)}

Bolboceras lateralis Westwood, 1848: 385 (description, distribution).

Bolbohamatum laterale, Krikken, 1980: 33, (description, keyed, distribution, illustration, comb. nov.)

Specimens examined: Madhya Pradesh: ZSI/CZRC-A16730; male (Length: $19.0 \mathrm{~mm}$; width: $12.0 \mathrm{~mm}$ ); Sitapar, Singhori Wildlife Sanctuary, Raisen; D. K. Harshay, 16 September 2009; day collection.

Diagnosis: (Fig. 7) Cephalic tubercles dentiform and placed on lateral margins. Paramedian tubercles of pronotum well separated by more than inter ocular distance. Lateral tubercles almost absent. Median cavity of pronotal disc absent. Punctation on pronotal disc abundant. Front tibia with eight denticles.

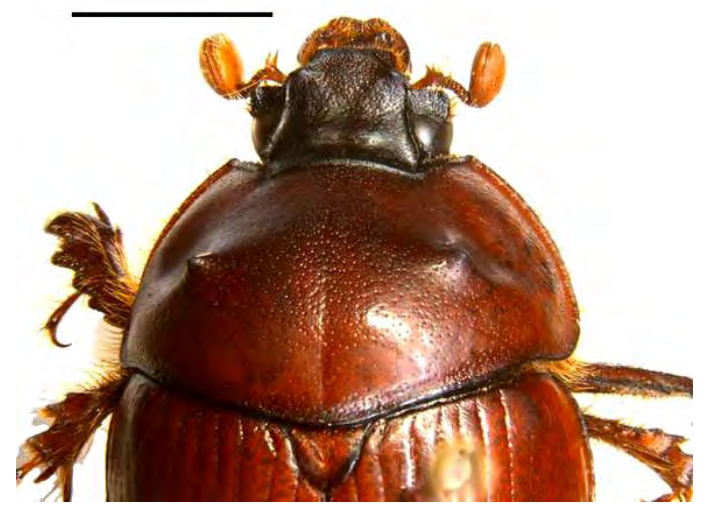

Figure 7: B. laterale (scale: $5 \mathrm{~mm}$ ), ZSI/CZRCA/16730, Singhori Wildlife Sanctuary, 2009.

External male genitalia: (Fig. 8) Apex of parameres dorsally with short reflexed paramerites. Basal capsule of phallus is robust but not too much extant as of $B$. marginale Krikken, 1980.

Geographical distribution: India: Assam, Maharashtra, Madhya Pradesh, Jammu \& Kashmir and Karnataka.

New state and district record: Madhya Pradesh (Raisen). 
Remarks: The species can be easily distinguished from its close members, $B$. marginale Krikken, 1980 and B. kuijteni Krikken, 1980 having only one pair of lateral pronotal protrusions and abundantly punctate pronotum.

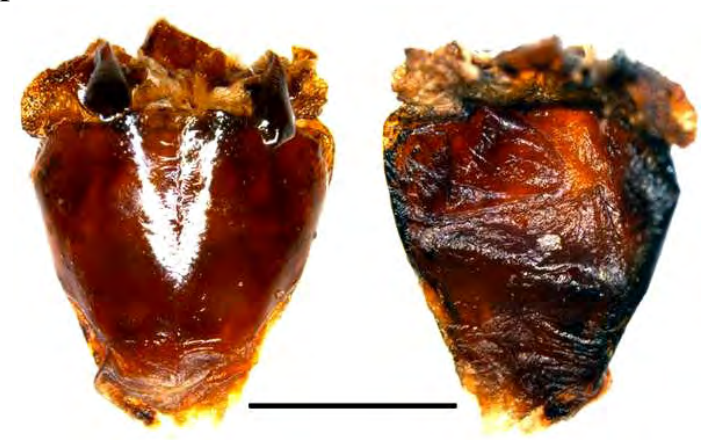

Figure 8: Dorsal \& ventral view of external male genitalia of $B$. laterale (scale: $2 \mathrm{~mm}$ ), ZSI/CZRCA/16730.

\section{Tribe: Bolbelasmini Nikolajev, 1996}

\section{Genus Bolbogonium Boucomont, 1911}

Bolbogonium Boucomont, 1911: 340 (as subgenus of Bolboceras Kirby; Type species: Bolboceras triangulum Westwood, 1852: 342).

Bolbogonium Krikken, 1977: 79 (stat. nov.).

Generic diagnosis: Middle coxae widely separated by an anterior lobe of pyriform metasternal disc. First antennal club segment on proximal side shiny and glabrous distinctly separated from surrounding pubescent surface. Seven elytral striae between elytral suture and humeral umbone and all virtually reaching base.

\section{Bolbogonium insidiosum Krikken, 1977}

Bolbogonium insidiosum Krikken, 1977: 95, (description, keyed, distribution, illustration).

Specimens examined: Madhya Pradesh: ZSI/CZRC-A/16605; male (Length: $9.0 \mathrm{~mm} \&$ width: $5.5 \mathrm{~mm}$ ); Kartoli, Singhori Wildlife Sanctuary, Raisen $\left(23^{\circ} 11.200^{\prime} \mathrm{N}, 78^{\circ} 12.085^{\prime}\right.$ ' E); S. S. Talmale; 13 December 2010; ZSI/CZRC-A/16778; male (Length: $8.0 \mathrm{~mm} \mathrm{\&}$ width: $5.0 \mathrm{~mm}$ ); Bhamori rest house, Singhori Wildlife Sanctuary, Raisen; S. Sambath \& Party; 17 September 2011; day collection.

Diagnosis: (Fig. 9 a, b) Yellowish brown, shiny and pilosity yellowish. Clypeal surface regulate punctate. Frons with three small isolated tubercles between eye-canthi. Vertex with large
U shaped, sparsely punctate impression. Pronotum with anterior declivity impressed and punctation generally sparse. Scutellum finely punctate. Elytral striae deeply impressed well defined and with large punctures. Elytral stria two extending further caudad. Front tibia with 8-9 denticles.

Geographical distribution: India: Madhya Pradesh, Maharashtra, Tamil Nadu and Uttar Pradesh.

New district record: Madhya Pradesh (Raisen). Remarks: The species shows variation in the shape of clypeus, ornamentation of frons and vertex. (Fig. 9 a, b).
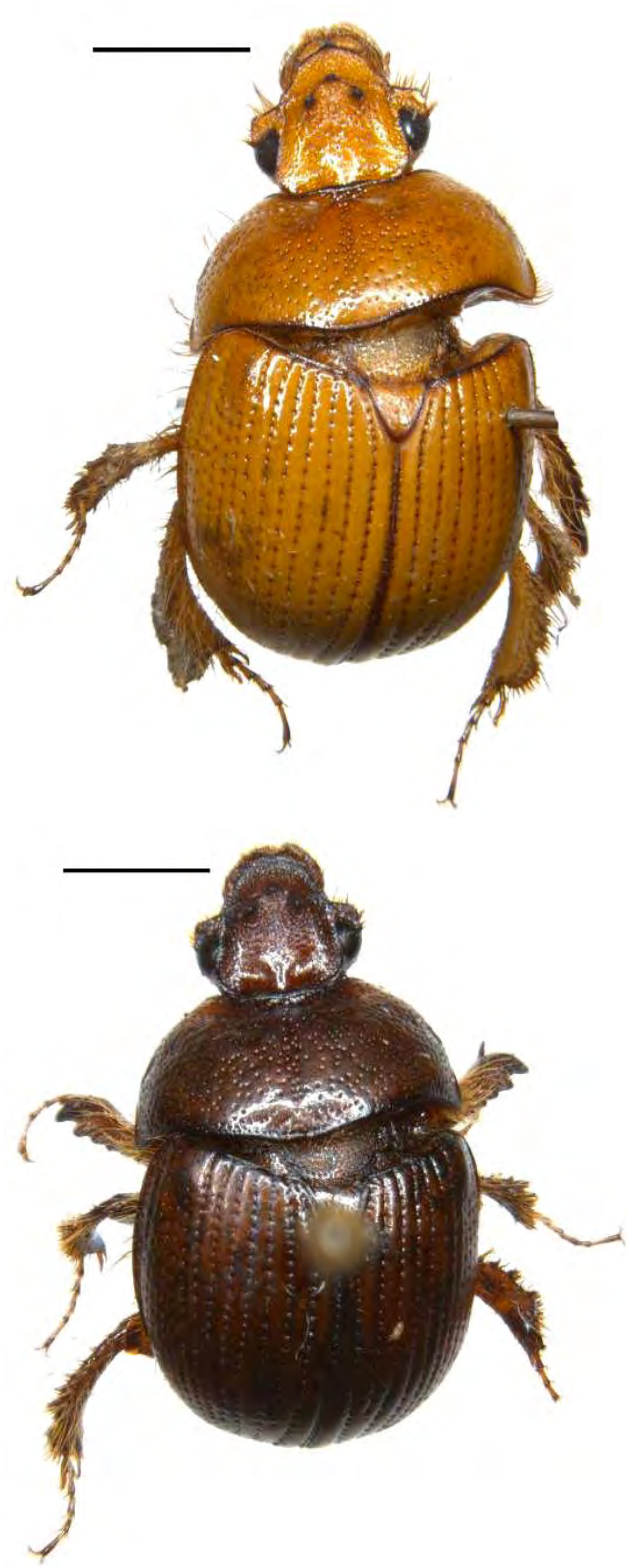

Figure 9: Variation of $B$. insidiosum (scale: $2 \mathrm{~mm}$ ), ZSI/CZRC-A/16605 \& 16778, Singhori Wildlife Sanctuary, 2010 \& 2011. 
Table 1: Checklist of genera Bolbohamatum and Bolbogonium from India

\begin{tabular}{|c|c|c|}
\hline \multirow{2}{*}{ Name of the species } & \multicolumn{2}{|l|}{ Distribution } \\
\hline & India (states) & Elsewhere \\
\hline \multicolumn{3}{|c|}{ Genus Bolbohamatum Krikken, 1980} \\
\hline B. cyclops (Olivier, 1789) & $\begin{array}{l}\text { Bihar, Himachal Pradesh, Madhya Pradesh, New } \\
\text { Delhi, Uttarakhand, Uttar Pradesh and West Bengal }\end{array}$ & Nepal \\
\hline B. calanus (Westwood, 1848) & $\begin{array}{l}\text { Assam, Bihar, Chhattisgarh, Karnataka, Madhya } \\
\text { Pradesh, Maharashtra, Tamil Nadu, West Bengal } \\
\text { and Uttarakhand }\end{array}$ & $\begin{array}{l}\text { Bangladesh } \\
\text { and Java }\end{array}$ \\
\hline B. phallosum Krikken, 1980 & Chhattisgarh, Maharashtra and Madhya Pradesh & \\
\hline B. pseudogrande Krikken, 1980 & Assam and Himachal Pradesh & \\
\hline B. robustum Krikken, 1980 & Himalayan Region & \\
\hline B. laevicolle (Westwood, 1848) & Assam, Maharashtra, Orissa and Himalayan Region & Bangladesh \\
\hline B. pyramidifer Krikken, 1980 & Orissa & \\
\hline B. meridionale Krikken, 1980 & Puducherry & \\
\hline B. marginale Krikken, 1980 & $\begin{array}{l}\text { Chhattisgarh, Madhya Pradesh, Tamil Nadu, } \\
\text { Karnataka and Uttarakhand }\end{array}$ & Pakistan \\
\hline B. kuijteni Krikken, 1980 & Maharashtra & \\
\hline B. laterale (Westwood, 1848) & $\begin{array}{l}\text { Maharashtra, Madhya Pradesh, Sikkim, Jammu \& } \\
\text { Kashmir, Karnataka and West Bengal }\end{array}$ & \\
\hline
\end{tabular}

Genus Bolbogonium Boucomont, 1911

\begin{tabular}{l|l|c} 
B. bicornutum Krikken, 1977 & West Bengal & Pakistan \\
\hline B. howdeni Krikken, 1977 & Bihar & Afghanistan \\
\hline B. impressum (Wiedemann, 1823) & Himachal Pradesh and Uttarakhand & Bangladesh \\
\hline B. insidiosum Krikken, 1977 & $\begin{array}{l}\text { Karnataka, Madhya Pradesh, Maharashtra, Tamil } \\
\text { Nadu and Uttar Pradesh }\end{array}$ & \\
\hline B. davatchii (Baraud, 1973) & $\begin{array}{l}\text { Jammu \& Kashmir, Himachal Pradesh, Uttar } \\
\text { Pradesh and Uttarakhand }\end{array}$ & $\begin{array}{c}\text { Iran } \\
\text { 2008) }\end{array}$ \\
\hline B. punctatissimum (Westwood, 1852) & Uttar Pradesh & \\
\hline B. scurra Krikken, 1977 & Tamil Nadu & $\begin{array}{c}\text { Myanmar, } \\
\text { Bangladesh } \\
\text { P. triangulum } \text { (Westwood, 1852) }\end{array}$ \\
\hline
\end{tabular}

\section{Acknowledgements}

The authors are thankful to K. Venkataraman (Director, ZSI) for providing necessary facilities and encouragement.

\section{Literature cited}

Boucomont, A., 1911. Contribution à la classification des Geotrupidae (Coleoptera), Annales de la Société entomologique de France, 79: 335-350.

Carpaneto, G. M., R. Mignani and E. Piatella, 1993. A revision of the Afro-Indian genus Bolboceratops (Coleoptera, Scarabaeoidea, Geotrupidae), Journal of African Zoology, 107: 329-353.
Kral, D., I. Löbl and G. V. Nikolajev, 2006. Bolboceratidae. In: Catalogue of the Palaearctic Coleoptera - 3. Löbl, I. and A. Smetana (eds.). Apollo Books, Stentrup, Denmark: 82-84.

Krikken, J., 1977a. The genus Bolbelasmus Boucomont in Asia, with notes on species occurring in other regions (Coleoptera: Geotrupidae). Zoologische Mededelingen, 51 (17): 278-292.

Krikken, J., 1977b. Asian bolboceratine scarabs of the genus Bolbogonium Boucomont (Coleoptera-Geotrupidae), Tijdschrift voor Entomologie, 120 (3): 77-108. 
Krikken, J., 1978a. The Afro-Asian Bolboceroides validus group (Coleoptera; Geotrupidae), Zoologische Mededelingen, 52 (26): 301-311.

Krikken, J., 1978b: Taxonomic notes on Bolboceras indicum Westwood and its relatives (Coleoptera: Geotrupidae). Entomologische Berichten Amsterdam, 38: 72-77.

Krikken, J., 1979. The Genus Bolbocerosoma Schaeffer in Asia (Coleoptera: Geotrupidae), Zoologische Mededelingen, 54 (3): 35-51.

Krikken, J., 1980. Bolboceratine scarabs of the Oriental genus Bolbohamatum nov. (Coleoptera, Geotrupidae), Tijdscrift voor Entomologie, 123: $1-38$.

Krikken, J., 1984. A generic reclassification of the Afrotropical Bolboceratini (Coleoptera: Geotrupidae). Zoologische Mededelingen, 58: 2345 .

Li, C. L., C. C. Wang, K. Masumoto, T. Ochi and P. S. Yang, 2008. Review of the Tribe Bolboceratini s.l. from Taiwan (Coleoptera: Scarabaeoidea: Geotrupidae) with a Key to the Eurasian Genera. Annales of the Entomological Society of America, 100 (3): 474-490.

Masumoto, K., 1984. New coprophagous Lamellicornia from Japan and Formosa. The Entomological Review of Japan, 39 (1): 73-83.

Nikolajev, G. V., 1970. Taxonomic status of the groups belonging to the subfamily Geotrupinae. Results of the Second Scientific Conference of Young Specialists and Postgraduates, celebrated 100 years from the date of birth of V. I. Lenin and 50 years from the date of origin of Kazakhstan: 31-34.

Nikolajev, G. V., 1979a. Eine neue BolbelasmusArt aus Asien (Coleoptera, Scarabaeidae, Bolboceratinae. Reichenbachia, Staatliciies Museum fur Tierkunde in Dresden, 17 Nr. 27, 225-227.

Nikolajev, G. V., 1979b. Neue Gattungen und Untergattungen der Blatthornkäfer (Coleoptera, Scarabaeidae). Reichenbachia, Staatliciies Museum fur Tierkunde in Dresden, 17 Nr. 23, 189-191.
Nikolajev, G. V., 2003. The taxonomic composition of the subfamily Bolboceratinae from the Palaearctic faunistic region. Tethys Entomological Research, 8: 187-206.

Nikolajev, G. V., 2008. On the systematic position of Iranian species Bolboceras davatchii Baraud, 1973 (Coleoptera: Scarabaeoidea), Caucasian Entomological Bulletin, 4 (2): 199201.

Ochi T. and M. Kawahara, 2002. Description of the female of Bolbelasmus shibatai Masumoto, 1984. Kogane, 3: 31-33.

Ochi T. and K. Masumoto, 2005. Systematic Position of Bolbelasmus ishigakiensis Masumoto Elytra, 33 (2): 244

Ochi T., K. Masahiro and K. Masakazu, 2010. A new species of Bolbochromus from the Philippines (Coleoptera, Scarabaeidae). Kogane, 11: 97-99.

Ochi T., M. Kon and M. Kawahara, 2011. Four new taxa of Scarabaeoidea from Southeast Asia. Special Publication of the Japanese Society of Scarabaeoidology, Tokyo 1: 153-162.

Scholtz, C. H. and D. J Browne, 1996. Polyphyly in the Geotrupidae (Coleoptera: Scarabaeoidea): a case for a new family. Journal of Natural History, 30: 597-614.

Smith, A. B. T., 2006. A Review of the FamilyGroup Names for the Superfamily Scarabaeoidea (Coleoptera) with Corrections to Nomenclature and a Current Classification, Coleopterists Society. Monograph Number, 5: 144-204.

Westwood, J. O., 1848. Description of some new or imperfectly known species of Bolboceras, Proceedings of the Linnaean Society London, 1: 384-387.

Westwood, J. O., 1852. Descriptions of some new or imperfectly known species of Bolboceras Kirby, Transactions of the Linnean Society London, 21: 19-30. 